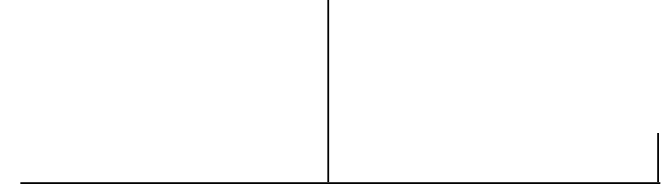

Rev. Latinoam. Psicopat. Fund., São Paulo, v. 11, n. 1, p. 97, março 2008

\title{
Peter Duesberg e a relação entre o HIV e a Aids: o ponto de vista de um cientista contra o mainstream
}

Mônica Teixeira

Na edição passada da Revista Latinoamericana de Psicopatologia Fundamental (v. 10, n. 4, p. 664-676, dez.2007), Observando a Medicina apresentou o ponto de vista divergente de um cientista da Universidade da Califórnia em Berckeley, sobre que fenômeno dá lugar ao surgimento dos cânceres. O cientista chama-se Peter Duesberg; tem uma sólida carreira como virologista e biólogo molecular. Nasceu em 1936 na Alemanha, mas trabalha desde a década de 1980 nos EUA, e gosta demais de discordar.

A discordância mais célebre que Duesberg protagonizou escandalizou os meios acadêmicos e muitos participantes de organizações que trabalham na prevenção da epidemia de AIDS: o cientista, em 1988, afirmou que o HIV não causa a Síndrome da Imunodeficiência Adquirida. É a integra da carta à revista Science em que Duesberg comunica sua discordância, e a resposta formulada a ela por outros cientistas, que publicamos nesta edição.

\section{Mônica TeIXeira}

Jornalista na TV Cultura e coordenadora do Núcleo de Pesquisas e Desenvolvimento de Novas Tecnologias para a TV pública; psicanalista; coordenadora do Laboratório de Saúde Mental da Associação Universitária de Pesquisa em Psicopatologia Fundamental (São Paulo, SP, Brasil); organizadora do livro Universidade e governo: professores da Unicamp no período FHC (Escuta, 2003).

Av. Higienópolis, 318/13 01238-001 São Paulo, SP, Brasil e-mail: armonica@uol.com.br 